\title{
THE IMPACT OF COVID-19 TOWARDS HUMAN SECURITY
}

\author{
Iqbal Ramadhan *) \\ ${ }^{*}$ International Relations Department, Universitas Pertamina, iqbal.ramadhan@universitaspertamina.ac.id
}

\section{ABSTRACT}

The emergence of coronavirus at the end of 2019 caused the world to fall into a global pandemic. It cannot be denied that the phenomenon of the Covid-19 pandemic caused a downturn in the global economy. The threat of the Covid-19 pandemic has endangered social aspects and has also destabilized the political and economic life of all countries. Covid-19 has an impact on human security around the world. The concept of human security essentially emphasizes human freedom from fear. Through the concept of human security, this article seeks to explain how people are classified as vulnerable objects. Their lives could be threatened by Covid-19. The author uses a qualitative methodology with case study techniques to address this issue. The analysis in this article shows that poor, undernourished people who do not have access to sanitation and health services live in densely populated areas and people with comorbidities are particularly vulnerable to exposure to Covid-19. The conclusion of this research is that the government needs to give priority to these vulnerable communities. They are the entities that need to be protected from the threat posed by Covid-19.

Keywords: Covid-19, Human Security, Security Studies, Vulnerability

\section{ABSTRAK}

Munculnya virus corona di penghujung tahun 2019 menyebabkan dunia terjerumus ke dalam pandemi global. Tak bisa dipungkiri, fenomena pandemi Covid-19 menyebabkan perlambatan ekonomi global. Ancaman pandemi Covid-19 telah membahayakan aspek sosial dan juga mengguncang kehidupan politik dan ekonomi semua negara. Covid-19 berdampak pada keamanan manusia di seluruh dunia. Konsep keamanan manusia pada dasarnya menekankan kebebasan manusia dari rasa takut. Melalui konsep human security, artikel ini berusaha menjelaskan bagaimana manusia diklasifikasikan sebagai objek yang rentan. Hidup mereka bisa terancam oleh Covid-19. Penulis menggunakan metodologi kualitatif dengan teknik studi kasus untuk mengatasi masalah ini. Analisis dalam artikel ini menunjukkan bahwa orang miskin dan kurang gizi yang tidak memiliki akses ke sanitasi dan layanan kesehatan tinggal di daerah padat penduduk dan orang dengan penyakit penyerta sangat rentan terhadap paparan Covid-19. Kesimpulan dari penelitian ini adalah bahwa pemerintah perlu memberikan prioritas kepada masyarakat rentan tersebut. Mereka adalah entitas yang perlu dilindungi oleh pemerintah dari ancaman Covid-19.
\end{abstract}

Kata Kunci: Covid-19, Keamanan Manusia, Studi Keamanan, Kerentanan 


\section{BACKGROUND}

The end of 2019 and the beginning of 2020 are important years in human history. This year, the world again faced a global infectious epidemic that had hit 100 years earlier. Recently, a new virus called SARS Cov-2 has struck humanity and has caused an economic crisis. This illness first emerged in China at the end of December of the current year (Liu, Kuo, \& Shih, 2020, p. 1). Some medical experts and doctors claim that this virus is zoonotic (Liu, Kuo, \& Shih, 2020, p. 2). This virus spreads from one animal species to human being. A medical expert claims that bats are the main carriers of this virus (Liu, Kuo, \& Shih, 2020, p. 2). How did this virus spread internationally? The Wuhan market appears to be the first spot the virus is emerging in. Wild animals are sold at Wuhan Market as food and medicine (Shereen, Suliman, Kazmi, Bashir, \& Siddique, 2020, p. 91). The disease spreads from an infected bat to a secondary host, the pangolin. Then this virus infected humans and eventually spread throughout the world (Shereen, Suliman, Kazmi, Bashir, \& Siddique, 2020, p. 93) . Experts assume that humans may be infected with the coronavirus by consuming unclean meat. Ultimately the virus mutates and evolves from unknown human to human source (Shereen, Suliman, Kazmi, Bashir, \& Siddique, 2020, p. 91).

The coronavirus becomes a buzz word and an ongoing subject of debate worldwide. The virus jump-started the development of a new disease called Covid-19. Covid-19 has the same symptoms as other diseases that define acute respiratory disorders, including severe acute respiratory syndrome (SARS) and Middle East respiratory syndrome (MERS) (MERS) (Hakim, et al., 2020, pp. 18-19). The SARS virus first appeared in 2003, and the MERS virus in 2012. Like other emerging diseases, bats are thought to be one of the key causes of the emergence (Hakim, et al., 2020, p. 19). However, in MERS' case it is suspected that camels are the second host species for the transmission of the same virus from bats before it finally spreads to humans (Shereen, Suliman, Kazmi, Bashir, \& Siddique, 2020, p. 93). People infected with this disease can experience high fever, dry cough, loss of taste and smell, and muscle pain, and in some cases, nausea, and diarrhea (Wu, Chen, \& Chan, 2020, p. 218). This virus spreads easily, and is potentially dangerous to the elderly and those with other underlying medical conditions (Wu, Chen, \& Chan, 2020, p. 218). The rapid and widespread spread of this disease has led the World Health Organization to declare it as a global pandemic (WHO, 2020). Based on figures from Worldometer, the number of cases of patients infected with Covid-19 totaled 106,003,626 cases. The number of people who died was 2,311,001 and the number of people who survived reached 77,643,019. The total number of open cases reached 25.9 million, and the number of closed cases reached 80.1 million. (Worldometers, 2021)

2 | Jurnal Ilmu Sosial dan Ilmu Politik Malikussaleh (JSPM) Volume 2 Nomor 1 Tahun 2021 
The advent of the Covid-19 pandemic has triggered concerns in various scientific fields resulting in testing, analysis, and examining of the danger of the pandemic. One of the fields of science that also examines the Covid-19 phenomenon is security studies. This scientific article analyzes the impact of Covid-19 on the human security. Based on the United Nations Development Program (UNDP), at least seven aspects of human security must be met in order for a country to have a prosperous society (Gomez \& Gasper, 2013, p. 1). One part of the dilemma is the health effect. The organization claims that certain factors are important to make a society prosperous (Gomez \& Gasper, 2013, p. 1). To achieve these seven aspects of human security the mechanism should be based on human empowerment and community development (Gomez \& Gasper, 2013, p. 7). Security problems posed by the Covid-19 pandemic have an important effect on the public's health. As the highest authority of a state, the state's duty is to protect its people from disease (Yukping \& Thomas, 2010, p. 448). When the state is careless in this area, human rights have been violated (Yuk-ping \& Thomas, 2010, p. 448). Covid-19 has become a real hazard, and its potency is growing. The problem of the danger of a pandemic crosses national borders or no individuals have any influence over the threat (Chattu, Knight, Reddy, \& Aginam, 2019, p. 3). To be noted, it is worth noting there are groups of people who are especially vulnerable to threats posed by a pandemic. They are the poor, the malnourished, people with chronic illnesses, people with comorbidities, people with minimal access to sanitation, classes of people who do not have access to health facilities such as clinics and hospitals, and people who live in slums or crowded/poor areas (O'Manique \& Fourie, 2010). The seven categories above are the most vulnerable people to the threat of pandemic diseases. On the other hands, people who are affected by Covid-19 often face negative stigma from the society (Dwinanto \& Sumarni, 2020, p. 3). In addition, according to UNDP, human security is focused on human freedom from fear (Gomez \& Gasper, 2013 , p. 1). The aim of this article is to analyze how the issue or phenomenon of Covid-19 is seen in security studies, in particular in the concept of securitization. In the beginning, the Covid-19 does not appear to be a threat that needs to be overcome. It requires a process known as securitization. The author's aim is to analyze how Covid-19 appears to be a real threat. The author will describe how the process of securitization is carried out by state actors. After emerging as a threat, the author will analyze how Covid-19 has a horrendous impact on society and how the state responds to mitigate this threat. The author also analyzes the relationship between Covid-19 and the concept of human security. The author will use the concept of securitization and human security to analyze this Covid-19 phenomenon.

3 | Jurnal Ilmu Sosial dan Ilmu Politik Malikussaleh (JSPM) Volume 2 Nomor 1 Tahun 2021 


\section{Previous Studies}

The authors reviewed previous studies and discovered a correlation between three human security issues and Covid-19 phenomenon. The researchers cited one of their reports, "Covid-19 between Global Human Security and Ramping Authoritarian Nationalism." The study investigated how the Covid-19 pandemic altered the economic status of the lower classes (Milani, 2020, pp. 143-144). A highlight of Milani's presentation was his discussion of Covid-19, which has the potential to disturb the equilibrium of social and economic life. Milani acknowledged the current economic condition and the fight for economic equality. The coronavirus will affect anyone regardless of their financial status (Milani, 2020, pp. 143-144). Milani has argued that economically vulnerable individuals are more prone to this virus attack. People living in crowded and deprived urban neighborhoods are the best carriers for the Covid-19 virus (Milani, 2020, p. 144). These people are usually poor and lack healthcare, clean water and even food. In sum, Milani stressed the need for international cooperation and collaboration to solve the problem of Covid-19. The imbalance of third world countries' suffering should be discussed if all nations agree that the challenge of Covid-19 is a global concern (Milani, 2020, p. 150).

Current research shows that Covid-19 poses as a nontraditional threat to human security. The research was performed by Siti Nurhasanah, Marthen Napang, and Syaiful Rohman. This article analyzes the role of security studies in understanding the Covid-19 phenomenon's threat to human security (Nurhasanah, Napang, \& Rohman, 2020, p. 54). This article discusses how the perspective of security studies explains the Covid-19 phenomenon as a non-traditional threat to human security. In their discussion, the authors discussed that non-traditional security discussed low politics issues (Nurhasanah, Napang, \& Rohman, 2020, p. 59). The issues discussed generally examine threats in the environmental, social, economic, and health sectors. Unlike conventional approaches that discuss topics such as politics and the military, non-traditional security identifies issues that are often left out of the focus of debate (Nurhasanah, Napang, \& Rohman, 2020, p. 59). However, non-traditional security risks have a direct effect on human lives. In addition, the debate in this study also addresses health as an integral dimension of human security (Nurhasanah, Napang, \& Rohman, 2020, pp. 61-62). The threat of Covid-19 has a direct impact on people's lives as this pandemic has slowed down economic growth. If economic development is stalled, it is strongly associated with people's health (Nurhasanah, Napang, \& Rohman, 2020, pp. 61-62). The study concludes that the state should take advantage of technical advances such as artificial intelligence to track and suppress the spread of the virus (Nurhasanah, Napang, \& Rohman, 2020, p. 66) s.

4 | Jurnal Ilmu Sosial dan Ilmu Politik Malikussaleh (JSPM) Volume 2 Nomor 1 Tahun 2021 
The previous study referred to by the author is "Global Covid-19 Responses from a Critical Security Studies Perspective." Lachlan Abbot wrote an article explaining that the most fundamental human security, specifically freedom from fear, is threatened by the Covid-19 pandemic (Abbot, 2021, p. 4). Abbot stressed that coronavirus would cross national boundaries without being detected. If many people are infected with Covid-19 and the disease spreads across the world, it would be a problem for all countries (Abbot, 2021, p. 4). In his statement, Abbot clarified that the closing of the country's border areas would not be convenient. Some countries are also introducing isolationism policies. The closing of national boundaries would only impede the flow of medical assistance (Abbot, 2021, pp. 4-5). Of course, medical assistance is required for those who fall into the category of disadvantaged people living in heavily populated areas (Abbot, 2021, pp. 4-5). In conclusion, Abbot proposes a humanist approach to overcoming the challenge of the Covid-19 pandemic. One of them is to put this problem as human-centric, not state-centric (Abbot, 2021, p. $5)$.

\section{The Concept of Human Security and Health Issues}

The definition and meaning of the concept of human security is still under discussion. There are at least two narrow and broad definitions of this concept. In a narrow sense, human security can be interpreted as free from fear and wants (Gomez \& Gasper, 2013, p. 1). However, the UNDP points out that human security is a right for all to live freely and to have dignity and to avoid the threat of poverty and despair (Gomez \& Gasper, 2013, p. 1). In practice, the concept of human security must protect people from severe threats that may prevent them from gaining access to fundamental rights (Ahsan, 2016, p. 30). Human security development therefore considers the integration of all aspects of state life, such as the strengthening and improvement of political, economic, social, cultural and environmental systems (Ahsan, 2016, p. 30). The development of an integrated system seeks to protect seven fundamental human rights in terms of human security, notably economic, health, food, environment, personal, community and policy (Gomez \& Gasper, 2013, p. 1). This study can map the types of threats that could hamper human beings from achieving their fundamental rights (Gazizulin, 2016, p. 2). Each of these threats has the potential to endanger the value of human life if it is not addressed. It is therefore necessary for actors such as the state to take mitigation measures to anticipate such threats (Gasper \& Gomez, 2015, p. 4).

Health issues are an essential part of achieving human development that is aligned with the concept of human security. It is undeniable that, in this new millennium era, the world is presented with a number of new diseases such as Ebola, Severe Acute Respiratory Syndrome (SARS) and 
HIV / AIDS (O'Manique \& Fourie, 2010, p. 245). The disease can become a pandemic unless it is managed by those who have legitimacy (O'Manique \& Fourie, 2010, p. 245). Health issues are important factors in security studies due to a paradigm shift from traditional to non-traditional threats (O'Manique \& Fourie, 2010, pp. 246-247). Indeed, this issue is related to the concept of human security as described above. The lack of access to health in developing countries is correlated in such a way that many people are vulnerable to various diseases (O'Manique \& Fourie, 2010, p. 246). In addition, those affected by the disease will undoubtedly make it difficult for them to obtain other fundamental human rights (O'Manique \& Fourie, 2010, p. 246). The important thing that needs to be emphasized from health issues in security studies is that the reference objects are not state but human (O'Manique \& Fourie, 2010, p. 249). This, however, has an indirect impact on the survival of the country. One example is that the more people who get sick, the wheels of government and the economy will stop (O'Manique \& Fourie, 2010, p. 245). The mitigation of the threat of new diseases is therefore an essential step in safeguarding fundamental human rights and the political and economic stability of the country.

\section{METHODOLOGY}

The approach used in this analysis was qualitative. Qualitative methods explain social processes and phenomena without using a numerical or mathematical approaches (Creswell, 2014, p. 232). Qualitative research generally allows a researcher to interpret perspectives, values, meanings, and social phenomena textually (Hammarberg, 2016, p. 499). Qualitative methodology analyzes social phenomena using language as scientific thinking to uncover meaningful trends in social behaviors (Hammarberg, 2016, p. 499). The authors are using pragmatism approach to explain the Covid-19 phenomenon. A pragmatism approach encourages researchers to select the type of research method openly, depending on the best methodology (Creswell, 2014, p. 232). Meanwhile, the reflexivity approach helps researchers to enter their perspectives into the research process at the analysis stage (Creswell, 2014, p. 232). In relation to the writing technique, the writer provides a case study. The researcher discusses how a case of international relations will influence one variable against another (Roselle \& Spray, 2012, p. 61). Regarding data collection, the author the author refers to Creswell's argument that researchers mainly gather data through observation and questioning and that secondary data (e.g., papers, records, audio-visual documents, and data from reputable institutions) can also be used (Creswell, 2014, p. 240). The author uses secondary data to reinforce the argument at the analysis stage.

6 | Jurnal Ilmu Sosial dan Ilmu Politik Malikussaleh (JSPM) Volume 2 Nomor 1 Tahun 2021 


\section{DISCUSSION}

With the spread of the Covid-19 pandemic, we have all been captivated. The Covid-19 pandemic is a major concern, and it will affect political, economic, and social stability. The danger from Covid-19 is a statewide concern that needs state and societal attention. The first thing to note is that diseases threaten all people, regardless of ethnicity, nationality, or culture (Rokvic \& Zoran, 2015, p. 55). The emergence of a pandemic epidemic concerns one country, but also has an effect on other nations (Rokvic \& Zoran, 2015, p. 55). The threat of diseases such as Covid-19 is invisible, but it is hazardous to human security (Rokvic \& Zoran, 2015, p. 55). The protection of human health is vulnerable to disease because it can be shielded from being seen. Disease risks are difficult to identify and can easily spread from country to country (Rokvic \& Zoran, 2015, p. 55). To detect Covid-19 threat, a large number of medical personnel and sophisticated instrumentation is needed (Smith III, 2016, p. 2). Many countries must develop strategic plans to prevent a pandemic from devastating their populations (Smith III, 2016, p. 2). The characteristics of the threat of a pandemic disease are very destructive to harm the community's political, economic, and social life (Herington, 2010, p. 486). The severity of a pandemic has the potential to radically change the current international social/political system (Herington, 2010, p. 486).

The state has a responsibility to ensure human security in the health sector, most notably from disease threats. Mitigation initiatives play a vital role in ensuring a country's existence from disease. The plan for reacting to any of Covid-19's threat is up to the government. The paper written by Joao Nunes suggests that policy intervention efforts are important and not just medical aspect (Nunes, 2012, p. 151). According to Nunes' statement, the government should identify numerous disease risks to its people and resolve them to ensure their overall health is not compromised (Nunes, 2012, p. 152). Therefore this statement is important for countries on how to mitigate these risks (Nunes, 2012, p. 152). If these measures are not enforced, the state will be in turmoil, and people's lives will be in jeopardy (Nunes, 2012, p. 153). The country's weak infrastructure and poor leadership has contributed to serious wars, coups, and foreign conflicts (Nunes, 2012, p. 154). This problem causes a domino effect which leads to a wave of refugees fleeing their homes. Those from countries that have been overcome by the threat of disease can allow them to flee to countries where they can have access to better health (Nunes, 2012, p. 154). Immigrants eventually will transmit diseases such as Covid-19, and refugee camps are the perfect place for such diseases to spread (Nunes, 2012, p. 154). Mitigation and identification policies are what the state must provide in order to ensure the welfare of its citizens (Smith III, 2016, p. 3).

7 | Jurnal Ilmu Sosial dan Ilmu Politik Malikussaleh (JSPM) Volume 2 Nomor 1 Tahun 2021 
This threat from Covid-19 is threatening all human beings from all walks of life. However, Covid-19 is going to be more deadly to people who have vulnerabilities. If the state neglects this, the state has violated human rights. There are at least seven indicators of people at risk of disease: poor people, malnutrition, chronic diseases, congenital diseases, inadequate sanitation systems, overcrowded places, and limited access to health institutions such as clinics or hospitals (O'Manique \& Fourie, 2010, p. 249). These seven indicators should be a government priority. Poverty is still a major obstacle for all countries in the world. It is important to note that poverty is correlated with access to food availability (Lautensach, 2015, p. 6). If the poor cannot access food, they will suffer from malnutrition. In the meantime, nutrition is needed to develop the body's immunity to fight disease. Without an increase in human welfare, people will face difficulty achieving human safety from a health aspect (Lautensach, 2015, p. 6). Human protection against the threat of disease, in essence, does not protect only one individual. If an individual can be protected from illness, this protection will also affect the smallest community, such as the family (Lautensach, 2015, p. 6). Another thing that should not go unnoticed is that the status of failed states is usually vulnerable to alleviation of the threat of new diseases (Quinn, et al., 2014, p. 17). Failed states are generally full of conflict. People living in conflict-ridden countries generally do not have access to health institutions or the capacity to fulfill their clothing and food requirements (Quinn, et al., 2014, p. 17). The threat of Covid-19 will therefore have a serious impact on people living below the poverty line.

The dimensions of poverty are positively correlated with each other. The vulnerability of the poor is exacerbated by lack of access to sanitation and availability of food. The state has the authority to address poverty by empowering people living in poverty with education and opening up easy access to health services (Periago, 2012, p. 357). Because, in the end, the country will be confronted with questions about how to minimize the threat of disease among the poor (Periago, 2012, p. 357). People living below the poverty line are very vulnerable to the threat posed by Covid19. Toddlers and young children from low-income families will be vulnerable to Covid-19 disease due to malnutrition (Headey, et al., 2020, p. 519). The study explains that some 47 million children from poor communities in South Asia and Sub-Saharan Africa are very vulnerable to Covid-19 (Headey, et al., 2020, p. 519). Poverty causes them to be undernourished. Children from poor communities, especially those living in the Sub-Saharan region, must face the threat of two deadly diseases at once, such as Ebola and Covid-19 (Headey, et al., 2020, p. 519). As a direct consequence, malnutrition results in immunity reduction and children are not immune to the threat of a pandemic. In the face of the threat of the Covid-19 pandemic, nutrition is needed for humans. 
Lack of nutrition causes the process of human recovery after exposure to Covid-19 to be longer and more complicated (Handu, Moloney, Rozga, \& Cheng, 2020, p. 1). Optimal nutrition is correlated with increased body immunity (Handu, Moloney, Rozga, \& Cheng, 2020, p. 1). The poor are close to malnutrition because they have no income to meet their daily nutritional needs. Meanwhile, one of the economic indicators of the decline in the number of undernourished people is the increase in the economic income of the community (Waibel \& Hohfeld, 2016, p. 13).

One of its challenges is the country's authority to respond to the threat posed by Covid-19 in this era of pandemics. In order to meet the country's human security achievements, they must ensure that all their people are safe from the threat. The threat of Covid-19 is going to be very deadly among the poor. The problem of malnutrition that they face is only the first surface of the problem. Sanitation is another thing that is very difficult for the poor to have access to. Achieving human security can be achieved if all parties are guided by the poverty strategy of the Sustainable Development Goals (SDGs) and the provision of access to clean water sources (Angoua, Dongo, Templeton, Zinsstag, \& Bonfoh, 2018, p. 2). For example, some 55\% of sub-Saharan Africa live below the poverty line (Angoua, Dongo, Templeton, Zinsstag, \& Bonfoh, 2018, p. 2). Meanwhile, 70 per cent of Sub-Saharan people did not have access to adequate sanitation in 2015 (Angoua, Dongo, Templeton, Zinsstag, \& Bonfoh, 2018, p. 2). In the case of the current Covid-19 pandemic, sanitation is needed to minimize the threat of the disease. Medical science itself recommends that people maintain hand hygiene today (Lotfinejad, Peters, \& Pittet, 2020, p. 776). The World Health Organization (WHO) has encouraged all countries to provide clean water in public places such as homes, schools and markets so as to minimize the threat of Covid-19 disease (WHO, 2020). The provision of clean water is a challenge for the state, in particular the distribution of clean water among the poor. In the end, the lack of clean water exacerbates the situation of the poor. The lack of access to clean water will facilitate the development of new diseases that have long emerged in poor communities, such as digestive diseases and mosquito-borne diseases (Adams, Stoler, \& Adams, 2020, pp. 2-3). Another empiric example is Indonesia, which currently has access to clean water for only $72 \%$ of the country's population (Purnama \& Susanna, 2020, p. 8). On the other hand, the SDG stipulates that the standard of public access to clean water in a country is $100 \%$ (Purnama \& Susanna, 2020, p. 8). Calculated for the number of people, some 33.4 million Indonesians do not have access to clean water (Purnama \& Susanna, 2020, p. 8). Indonesia will be called upon to provide clean water to all people in the fight against the threat posed by Covid-19. For example, state actors can cooperate bilaterally with international organizations to overcome the availability of clean water (Auliya \& Kusumawardhana, 2019, p. 342). 
The State, as one of the actors in the field of security studies, needs to take steps to mitigate the threat posed by Covid-19, which is consistent with the concept of human security. The ease of access to health institutions is another indicator of the dimensions of human security in the context of health. Poverty prevents the poor from having their basic rights in the health sector. Poverty has a very large social impact, such as health inequalities (Shahid, 2018, p. 111). If the poor do not have access to health, their life expectancy will decrease (Shahid, 2018, p. 111). As a result, the poor will be more vulnerable to the survival of all diseases (Shahid, 2018, p. 111). It will be hard work to mitigate the threat of Covid-19 in this dimension. The states need to develop policies that facilitate access to health for the poor so that they can survive in the midst of the Covid-19 pandemic. One example is the Indonesian government, which has a policy of establishing task forces at the provincial and city levels (Djalante, et al., 2020, p. 8). They conduct tracking and mass testing policies for individuals or communities who are indicated to have symptoms of Covid-19 disease (Djalante, et al., 2020, p. 8). The state must implement policies that are inclusive by not prioritizing access to health in certain circles and by developing a Covid-19 mitigation policy in accordance with the basic principles of human rights (Djalante, et al., 2020, p. 8).

Mitigation of the spread of Covid-19 in densely populated areas and individuals with comorbidities must give priority to the state. A study shows that human movements from one region to another make it easier for Covid-19 to spread rapidly (Rader, et al., 2020, p. 5). Densely populated areas are, however, one of the indicators that accelerate the distribution of Covid-19 (Rader, et al., 2020, p. 5). Densely populated areas are a challenge for the government to overcome the threat posed by Covid-19. The World Bank provides an example of how people living in slums and densely populated settlements are accelerating the spread of disease (World Bank, 2020). The lack of sanitation and access to public health institutions in slum areas is worsening poverty (World Bank, 2020). The World Bank recommends that all countries first immunize in slum areas when a vaccine has been found, allocate government funds to mitigate Covid-19 in slum areas and facilitate access to health for the poor (World Bank, 2020). The key argument that needs the attention of the government is that the dissemination of Covid-19 to the slum areas is obvious (Sahasranaman \& Jensen, 2020, p. 8). People living in slum areas typically have low wages and restricted access to clean water and health facilities (Sahasranaman \& Jensen, 2020, p. 8). When people are expected to fulfill their obligation to "stay at home and keep their distance," people living in heavily populated settlements would certainly have difficulties in fulfilling this obligation (Ghosh, Seth, \& Tiwary, 2020, p. 2). The number of inhabitants of the residential area is 5-7 people with a house area of just 25-35 square meters (Ghosh, Seth, \& Tiwary, 2020, p. 2). It is also not possible to 
implement a policy of "safe distance" in a high density settlement (Ghosh, Seth, \& Tiwary, 2020, p. 2). Further research is still needed on coronavirus spread in densely populated areas. However, people living in these areas are very vulnerable, hence they need more government attention (Friesen \& Pelz, 2020, p. 2).

Another last thing that must be prioritized by the government is the treatment of patients with comorbidities and chronic diseases. Patients with comorbidities such as diabetes, asthma and cardiovascular disease will be highly vulnerable to Covid-19 attacks (Liu, Chen, Liu, Nie, \& Lu, 2020, p. 7). Coronavirus ultimately amplifies the disease suffered by patient's attacks (Liu, Chen, Liu, Nie, \& Lu, 2020, p. 7). Several studies have shown that patients with comorbidities such as heart failure, high blood pressure, diabetes, kidney disease, hepatitis and stroke are at a high risk of death (Guan, et al., 2020). The mortality rate for patients with comorbidities who need to be assisted by respiratory devices is 85.9 per cent (Filardo, et al., 2020, p. 7). Another significant point that should not escape the government's attention is that one of the empiric studies indicates that ethnic minorities (Black and South Asian minorities) in the United States and Britain are most at risk of contracting Covid-19, especially people who live < 65 years (Ghosh, Seth, \& Tiwary, 2020, p. 2). Governments of all countries therefore need to systematically map the Covid-19 threat mitigation strategy (Capano, Howlett, Jarvis, Ramesh, \& Nihit, 2020, p. 287). The Covid-19 problem is not just a health problem. Furthermore, the mitigation of the danger of Covid-19 is more about how countries should adopt inclusive policies to track, reduce and suppress the spread of coronary virus (Capano, Howlett, Jarvis, Ramesh, \& Nihit, 2020, p. 287). If the state is ignorant and seems reluctant to resolve the danger of Covid-19, the government has violated the nature of human security in its society. The mitigation step that the country must take includes patients with comorbidities as one of the clusters that must be prioritized. This policy must, of course, be inclusive and align with the concept of human security.

\section{CONCLUSION}

The threat posed by Covid-19 has threatened the social, economic and political stability of all countries. The wave of the Covid-19 pandemic has the propensity to endanger human life. In essence, human security insists that people must be free from terror. The harm caused by Covid19 has generated specific concerns for the poor, hunger, people who do not have access to sanitation and health care, people living in densely populated areas, and people with comorbidities. People who have this vulnerability must be given priority by the government. However, these disadvantaged people do not have the same resources as people with above-average wages. The 
state must also pay more attention to these marginalized populations so that human security can be sustained at all levels of society.

\section{BIBLIOGRAPHY}

Abbot, L. (2021). Global Covid-19 Responses Through a Critical Security Studies Perspective. Retrieved from https://www.e-ir.info/2021/01/20/global-covid-19-responses-through-a-critical-securitystudies-perspective/

Adams, E. A., Stoler, J., \& Adams, Y. (2020). Water Insecurity and Urban Pverty in The Global South: Implications for Health and Human Biology. American Journal of Human Biology, 1-12.

Ahsan, M. K. (2016). Revisiting the Concept of Human Security. Philosophy and Progress Vol. LIX (LX), $10-42$.

Angoua, E. L., Dongo, K., Templeton, M. R., Zinsstag, J., \& Bonfoh, B. (2018). Barriers to Access Improved Water and Sanitation in Poor Peri-Urban Settlements of Abidjan, Cote D'Ivoire. PLOS One, 1-13.

Auliya, A. A., \& Kusumawardhana, I. (2019). UNICEF and The Wash: Analisis Terhadap Peran UNICEF dalam Mengatasi Masalah Ketersediaan Air Bersih di India. Frequency of International Relations Vol.1 (2), 341-378.

Capano, G., Howlett, M., Jarvis, D. S., Ramesh, M., \& Nihit, G. (2020). Moiblizing Policy (In)Capacity to Fight Covid-19: Understanding Variations in State Responses. Policy and Society Vol.39 (3), $285-$ 308.

Chattu, V. K., Knight, A., Reddy, K. S., \& Aginam, O. (2019). Global Health Diplomacy Fingerprints on Human Security. International Journal of Preventive Medicine Vol.10 (204), 1-4.

Creswell, J. (2014). Research Design: Qualitative, Quantitative, and Mixed Methods Approaches (4th Eds). London: SAGE.

Djalante, R., Lassa, J., Setiamarga, D., Sudjatma, A., Indrawan, M., Haryanto, B., . . Warsilah, H. (2020). Review and Analysis of Current Responses to Covid-19 in Indonesia: Period of January to March 2020. Progress in Disaster Science Vol.6, 1-9.

Dwinanto, J., \& Sumarni. (2020). Human Security, Social Stigma, and Global Health: The Covid-19 Pandemic in Indonesia. Journal of The Medical Sciences Vol.52 (3), 74-81.

Filardo, T. D., Khan, M. R., Krawczyk, N., Galitzer, H., Karmen-Tuohy, S., Coffee, M., .. Cohen, G. M. (2020). Comorbidity and Clinical Factors Associated with Covid-19 Critical Illness and Mortality at a Large Public Hospital in New York City in The Early Phase of The Pandemic (March-April 2020). PLOS ONE, 1-16.

Friesen, J., \& Pelz, P. F. (2020). Covid-19 and Slums: A Pandemic Highlights Gaps in Knowledge About Urban Poverty. JMIR Public Health and Surveillance, 1-4.

Gasper, D., \& Gomez, O. A. (2015). Human Security Thinking in Practice: 'Personal Security', 'Citizen Security', and 'Comprehensive Mappings'. Contemporary Politics Vol.21 (1), 100-116.

Gazizulin, A. (2016). The Significance of The 'Human Security' Paradigm in International Politics. Retrieved from https://www.e-ir.info/2016/02/29/the-significance-of-the-human-securityparadigm-in-international-politics/

12 | Jurnal Ilmu Sosial dan Ilmu Politik Malikussaleh (JSPM) Volume 2 Nomor 1 Tahun 2021 
Ghosh, S., Seth, P., \& Tiwary, H. (2020). How Does Covid-19 Aggravate the Multidimensional Vulnerability of Slums in India? A Commentary. Social Sciences \& Humanities Open Vol.2, 1-5.

Gomez, O. A., \& Gasper, D. (2013). Human Security: A Thematic Guidance Note for Regional and National Human Development Report Teams. Retrieved from http://hdr.undp.org/sites/default/files/human_security_guidance_note_r-nhdrs.pdf

Guan, W. J., Liang, W. H., Zhao, Y., Liang, H. R., Chen, Z. S., Li, Y. M., . . . Tang, C. L. (2020). Comorbidity and Its Impact on 1590 Patients With Covid-19 in China: A Nationwide Analysis. European Respiratory Journal, 5-56.

Hakim, M. S., Annisa, L., Supriyati, E., W, D. E., Wibowo, R. A., Arguni, E., \& Nuryastuti, T. (2020). Current Understanding of The Origin, Molecular Biology and Continuing Evolution of Severe Acute Respiratory Syndrome Coronavirus 2 (SARS-CoV-2). Journal of The Medical Sciences Vol. $2(3), 17-29$.

Hammarberg, K. (2016). Qualitative Research Methods: When to Use Them and How to Judge Them. Human Reproduction Vol.31 (3), 498-501.

Handu, D., Moloney, L., Rozga, M., \& Cheng, F. W. (2020). Malnutrition Care During the Covid-19 Pandemic: Considerations for Registered Dietitian Nutritionist. Journal of The Academy of Nutrition and Dietetics, 1-9.

Headey, D., Heidkamp, R., Osendarp, S., Ruel, M., Scott, N., Black, R., . . Walker, N. (2020). Impacts of Covid-19 on Childhood Malnutrition and Nutrition-related Mortality. The Lancet Vol.396 (10250).

Herington, J. (2010). Securitization of Infectious Diseases in Vietnam: The Cases of HIV and Avian Influenza. Health Policy and Planning Vol.25, 467-475.

Lautensach, A. K. (2015). Sustainable Health for All? The Tension Between Human Security and The Right to Health Care. Journal of Human Security Vol.11 (1), 5-18.

Liu, H., Chen, S., Liu, M., Nie, H., \& Lu, H. (2020). Comorbid Chronic Diseases are Strongly Correlated with Disease Severity among COVID-19 Patients: A Systematic Review and Meta-Analysis. Aging and Disease Vol.11 (3), 668-678.

Liu, Y. C., Kuo, R. L., \& Shih, S. R. (2020). Covid-19: The First Documented Coronavirus Pandemic in History. Biomedical Journal, 1-5.

Liu, Y. C., Kuo, R. L., \& Shih, S. R. (2020). Covid-19: The First Documented Coronavirus Pandemic in History. Biomedical Journal, 1-5.

Lotfinejad, N., Peters, A., \& Pittet, D. (2020). Hand Hygiene and The Novel Coronavirus Pandemic: The Role of Healthcare Workers. Journal of Hospital Infection Vol.105, 776-777.

Milani, C. R. (2020). Covid-19 Between Global Human Security and Ramping Authoritarian Nationalisms. Geopolitica Vol.11, 141-151.

Nunes, J. (2012). Health, Politics, and Security. Open Edition Journal Vol.15, 142-164.

Nurhasanah, S., Napang, M., \& Rohman, S. (2020). Covid-19 As A Non-Traditional Threat to Human Security. Journal of Strategic and Global Studies Vol.3 (1), 54-68.

O'Manique, C., \& Fourie, P. (2010). Security and Health in Twenty-first Century. In V. Mauer, \& M. DunnCavelty, The Routledge Handbook of Security Studies (pp. 243-254). New York: Routledge.

Periago, M. R. (2012). Human Security and Public Health. Rev Panam Salud Public Vol.31 (5), 355-358.

13 | Jurnal Ilmu Sosial dan Ilmu Politik Malikussaleh (JSPM) Volume 2 Nomor 1 Tahun 2021 
Purnama, S. G., \& Susanna, D. (2020). Hygiene and Sanitation Challenge for Covid-19 Prevention in Indonesia. Kesmas: Jurnal Kesehatan Masyarakat Nasional Vol.1, 6-13.

Quinn, J. M., Martins, N., Cunha, M., Higuchi, M., Murphy, D., \& Bencko, V. (2014). Fragile States, Infectious Disease and Health Security: The Case for Timor-Leste. Journal of Human Security Vol.10 (1), 14-31.

Rader, B., Scarpino, S. V., Nande, A., Hill, A. L., Adlam, B., Reiner, R. C., . . Kraemer, M. U. (2020). Crowding and the Shape of Covid-19 Epidemics. Nature Medicine, 1-17.

Rokvic, V., \& Zoran, J. (2015). Health Issues as Security Issues. Vojno Delo Vol.6, 53-69.

Roselle, L., \& Spray, S. (2012). Research and Writing in International Relations. Boston: Pearson Longman.

Sahasranaman, A., \& Jensen, H. J. (2020). Spread of Covid-19 in Urban Neighbourhoods and Slums of The Developing World. J.R. Soc. Interface Vol.18, 1-9.

Sahlan, M., Kamil, A. I., Ilham, I., \& Amin, K. (2021). "Dari Ainal Madhiah Ke Si Kakek Merah" Ethnography of the Community Response Towards Covid-19 Pandemic. In International Conference on Social Science, Political Science, and Humanities (ICoSPOLHUM 2020) (pp. 209214). Atlantis Press.

Shahid, H. J. (2018). Poverty and Health: The Challenges for GPs. InnovAiT Vol.11 (2), 109-114.

Shereen, M. A., Suliman, K., Kazmi, A., Bashir, N., \& Siddique, R. (2020). Covid-19 Infection: Origin, Transmission, and Characteristic of Human Coronaviruses. Journal of Advanced Research, 91-98.

Smith III, F. L. (2016). Malware and Disease: Lessons from Cyber Intelligence for Public Health Surveillance. Health Security Vol.14 (5), 1-10.

Waibel, H., \& Hohfeld, L. (2016). Poverty and Nutrition: A Case Study of Rural Households in Thailand and Vietnam. Japan: Asian Development Bank Institute.

WHO. (2020). Coronavirus Disease 2019 (Covid-19) Situation Report - 94. Retrieved from https://www.who.int/indonesia/news/novel-coronavirus/situation-reports

WHO. (2020). Water, Sanitation, Hygiene, and Waste Management for Sars-Cov-2, the Virus that Causes COVID-19. Retrieved from https://www.who.int/publications/i/item/water-sanitation-hygiene-andwaste-management-for-the-covid-19-virus-interim-guidance

World Bank. (2020). Covid-19 and the Urban Poor Addressing Those in Slums. Retrieved from http://pubdocs.worldbank.org/en/304801589388481883/Addressing-COVID-19-and-the-UrbanPoor-SHORT-version-rev3-logos.pdf,

Worldometers. (2021). Covid-19 Coronavirus Pandemic. Retrieved from https://www.worldometers.info/coronavirus/?

Wu, Y. C., Chen, C. S., \& Chan, Y. J. (2020). The Outbreak of Covid-19: An Overview. Journal of The Chinese Medical Association Vol.83 (3), 217-220.

Yuk-ping, C. L., \& Thomas, N. (2010). How is Health a Security Issue? Politics, Responses, and Issues. Health Policy and Planning Vol.25, 447-453.

14 | Jurnal Ilmu Sosial dan Ilmu Politik Malikussaleh (JSPM) Volume 2 Nomor 1 Tahun 2021 